\title{
Classicized Hijazi: final short vowels and tanwīn
}

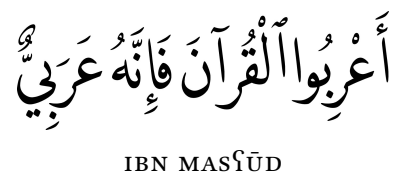

One of the quintessential features of Classical Arabic, but one that is strikingly elusive in both the epigraphic pre-Islamic record and the orthography of early Islamic Arabic is the presence of Pi $i$ räb and tanwin. Much has been said about the question whether this system was part of the spoken language, or purely part of a poetic oral tradition. Some authors argued that this case system must have been part of the general spoken register (e.g. Blau 1977) while others felt that it must have been purely part of the poetic performance (e.g. Zwettler 1978). These arguments have now for a large part been superseded by material evidence not available at the time. The view that everyone who spoke Arabic in the pre-Islamic period must have had the full inflectional system of Pi $r a \bar{b} b$ and tanwin can be discarded with certainty, as we now have thousands of inscriptions and papyri that prove the contrary (Al-Jallad and al-Manaser 2015; Al-Jallad 2015; 2017a; 2018a). This should change our perspective of what we should expect the inflectional system of the Quran to look like: if multiple varieties of Old Arabic from Syria and Jordan lacked the full inflectional system of Classical Arabic, how can we be certain that this is not also the case for the language of the Quran?

Blau appears to have not found such argumentation compelling because he considered Arabic in Syria and Jordan to be peripheral and, explicitly discussing the case system of Nabataean and what the implications may be for the language situation of the Hijaz, he concludes that "nothing must be inferred from border dialects for central dialects" (Blau 1977, 9). While certainly we must agree that one cannot conclude that just because the Proto-Arabic case system seems to have started to deteriorate in Nabataean Arabic, this must have necessarily been true for Hijazi Arabic as well, I see no reason to dismiss this possibility either, just because these varieties are "peripheral". In fact, it has long been recognized in dialectology that it is rather the peripheral dialects, 
where certain innovative waves may not reach are often the ones that tend to be most archaic (Owens 2006, 29). However, even taking Nabataean Arabic (and by extension Safaitic) as a "border dialects" and Hijazi Arabic as a "central dialect" rather belies an adherence to an unfounded assumption that it is indeed Nabataean Arabic that is peripheral and Hijazi Arabic that is central. As more and more pre-Islamic epigraphy, Arabic and otherwise, has become available it seems to become ever more clear that it is in fact Arabic spoken in Arabia that was the peripheral form of pre-Islamic Arabic, rather than central as the historiographical and genealogical myth making of the early Islamic empire may make us believe (Al-Jallad 2018b, 34).

Rather than relying on notions of periphery and centrality, we must rather turn our gaze to the data at hand. The fact that Old Arabic from Syria and Jordan lacked the full inflectional system known to Proto-Arabic - whether these varieties were peripheral or not - at least prove that such varieties did exist before Islam, and that the case system did not only begin its collapse at the start of (or even due to) the Islamic conquests as suggested, for example by Blau (1977, 16) and Versteegh $(1984,91)$. When referring to what the language of the Quran is, indeed nothing must be inferred from border dialects but they must not be inferred from central dialects either. The evidence of the Quran must speak for itself.

When addressing the question of the case system of the Quran however, certainly nothing must be inferred from statements by the Arabic grammarians, who seemingly admit no other option but speaking with full inflection. This is for two reasons. First, the grammarians are not contemporary with the Quran and therefore can hardly be considered direct witnesses of the language of the Quran. Second, the grammarians' treatment of the case system is highly ideological. They famously ignore the existence of non-inflectional forms of Arabic completely even in times where there can be little doubt this system had been lost completely in any vernacular spoken at the time, e.g. in the time of alZamaxšarī (d. 538/1143). One is hard pressed to find any admission that such forms of Arabic exist at all in his work, despite its disappearance in most, if not all, vernaculars. ${ }^{1}$

I will not discuss here whether the full inflectional system of Classical Arabic was part of the spoken register of some people, or a purely poetic register. For our current discussion, I do not think that this question is relevant. The ques-

1 The earliest admissions by grammarians that people do not quite seem to speak the way they prescribe the language seems to first start to appear in the fourth century AH, by alZağğăğì (d. 337/948) and Ibn Ğinnī (d. 392/1002), the latter however citing al-1axfaš al-Pawsat (d. 215/830) (see Blanc 1979, 171; Versteegh 1995, 96 f.; Larcher 2018). 
tion we should ask is whether the language of the Quran had a full inflectional system or not, a question which should be treated separately from the question of whether the system is proper to a vernacular or poetic register. Here we cannot turn to later sources, but we must base ourself on the earliest linguistic source that we have for the Quran: the QCT.

In an earlier article, my colleague Phillip W. Stokes and I have argued that, while the language of the Quran had not completely lost case inflection, the system had been significantly reduced (van Putten and Stokes 2018). We argue that word-final - $a n$ had shifted to $-\bar{a}$ and that all other forms of final short vowels and nunation (i.e. $-a,-i,-u,-u n$ and $-i n$ ) had been lost without a trace, not just in pause but also in connected speech. Only with nouns in construct, case appears to have been (perhaps optionally) retained. The arguments we present in favour of this view, rely on a careful study of the orthographic behaviour and internal rhyme patterns of the QCT. It seems worthwhile to summarize the main points here again, before we move on with the discussion.

1. Pausal spelling cannot account for the lack of marking of Pifräb and especially tanwīn.

The 1sg. endings - $n \bar{\imath}$ 'me' and - $-\bar{\imath}$ 'my' are shortened in pausal environments, and this is reflected in the orthography of the Quran only in pause. Had 'pausal spelling' been a general principle, we would expect this shortening to be reflected in the consonantal text consistently. To this we may now also add the appearance of a final $-h$ in pausal forms of the imperative and apocopate, which likewise only shows up in the QCT if such a word actually stands in a pausal position (see Appendix A.4.14). It therefore does not seem to be true that the orthography of the Quran always spells words as they are pronounced in pause. This therefore fails to explain the absence of signs for ?i $i$ rāb and especially tanwin in the spelling in non-pausal position.

While the feminine noun being usually spelled with $h \bar{a}$ ? in construct position is often invoked as evidence for the 'pausal spelling principle', it is nothing of the sort. The feminine noun in construct is unusual, and certainly orthographic, but its behaviour is unlike any other noun in construct, which are not spelled in their pausal form at all. For example, the construct form of banūna is simply spelled بنو in construct not in its

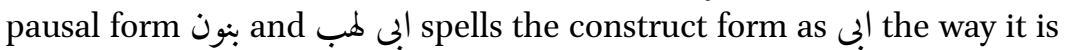
pronounced in construct as well, and not in its pausal form اب لـ اب who continue the myth that Arabic spelling is based on the pronunciation in pause are unjustly generalizing from the exceptional behaviour of the feminine ending to the orthography of the whole Quran. ${ }^{2}$

2 The explanation through a principle of pausal spelling is not a recent one, it is how the 
2. The distribution of the spelling of $t \bar{a} ?$ maftūhah and $t \bar{a}$ ? marbūtah for the feminine ending points to a dialectal distribution: -at in construct and - ah everywhere else.

The feminine ending is occasionally written with ت rather than $\alpha$, this invariably occurs when the noun stands in construct. In this position it is fairly common, occurring $22 \%$ of the time. Outside of construct it is

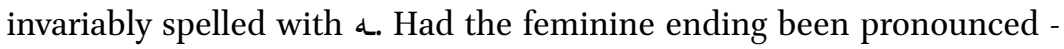
at in all non-pausal environments, we would be at a loss to explain why it is not spelled ت similarly often in non-construct, non-pausal position. What we find, however is that the feminine ending, in the $1800+$ times that the feminine ending is not in construct, not once is it spelled with . If we reasonably take the $22 \%$ of construct feminine nouns as the baseline for accidental phonetic spelling instead of pausal spelling, we would similarly expect non-construct feminines outside of pause to occur spelled with about $22 \%$ of the time, i.e. about 400 times. The actual score, however, is zero. This strongly suggests that outside of construct the feminine ending was never pronounced -at, not in pause nor in context. Thus, this distribution suggests that the feminine ending was always pronounced -ah except in construct where it was pronounced -at. So this distribution points to a morphology of the noun identical to that of modern Arabic dialects with -at in construct and -ah everywhere else. ${ }^{3}$

3. Internal rhyme suggests that "pausal" pronunciations were used in nonpausal positions ${ }^{4}$

Examples include: xayran la-hum rhyming with ?arhāma-kum $\left(\mathrm{Q}_{47: 21-}\right.$ 22), suggesting /xayrā la-hum/; and the rhyming epithet pairs in formu-

medieval Arab grammarians explained the unusual mismatch between the Arabic orthography and its classical pronunciation. For example, Ibn al-Sarrāğ (d. $316 \mathrm{AH})$ in his Kitāb al-Xațt lays out the principle explicitly: wa-l-Pașlu ?aydan fi kulli kalimatin ?an tuktaba Salā l-lafži bihā mubtada?atan wa-mawqüfan Salay-hä "And the principle is also that for each word that it be written with the pronunciation of it at the beginning of an utterance, and if it was paused upon." (Ibn al-Sarrāğ Kitāb al-Xatț, 67). We of course cannot blindly rely on a 4th c. AH source to tell us how the orthographic rules of the ist c. AH worked. The explanation is just as much a post hoc justification as it is for a modern scholar to hold this view.

3 In fact this exact distribution is seen as evidence for a modern dialectal type feminine ending in Middle Arabic texts (e.g. Blau 1967, § 24.1; 2002, 34; Blau and Hopkins 1987, §47a). If this argument is deemed convincing for Middle Arabic, it should also be accepted for Quranic Arabic.

4 For several examples of internal rhymes that seem to operate on "pausal" forms, see also Larcher (2014). In a recent article Larcher (2021) explores one more possible case of internal rhymes using pausal forms and, seemingly independently, explicitly adopts the same conclusions as Van Putten \& Stokes (2018). 
lae such as Pinna !̣̂âha samīiun Salìm (Q49:1) and wa-kāna !ḷähu Salìman hakīimā (Q48:4) suggesting /samīY Yalīm/ and / Yalīmā ḥakīmā/.

4. Several words reflect the regular outcome of the loss of the final short vowels and $n$, in places where they are not morphologically Pi $i \bar{r} a \bar{b}$ and tanwin.

For example, the apocopate "yakun spelled as يك (Q8:53) and the energic forms *la-nasfaSa-n and *la-yakünan being spelled لنسفع (Q9:15) and ليكون (Q12:32) respectively.

On the basis of these arguments, it seems likely to me that the Quran, far from having a fully classical Pi iräb/tanwin system as is generally believed, had a much reduced one. However, we cannot admit a full reworking of the text towards a Classical Arabic system by later grammarians/philologists from something more-or-less identical to the modern dialectal Arabic system as Vollers would have had it. This would have required a reworking of the QCT, we now have access to early manuscripts that closely follow the standard text that can be securely dated before the period of the development of Arabic grammatical theory, as its canonization almost certainly happened during the reign of Gutmān b. Yaffān. ${ }^{5}$

The absence of any transmission of reading traditions that lacked Pi riāb seems to have been the main objection of Nöldeke against Vollers' $i i$ i $r a \bar{b}$-less ur-Quran. A spirited defense of Vollers' hypothesis was put forward in three articles by Kahle (1947, 78-84; 1948, 163-182; 1949) who, aiming to counter Nöldeke's claim, proffers over a hundred prophetic, and non-prophetic narrations admonishing people not to read the Quran without Pi $i r a \bar{b}$. Many of these narrations must be outright fabrications, unless we accept that a full-fledged grammatical terminology was part of the common parlance of the prophet and his companions. Nevertheless, they show an important point: there were in fact people reading the Quran without Pi $i$ räb, and this was happening early enough that an authority as early as al-Farrā? (d. 207/822) felt the need to relate such narrations to discourage it. This made short work of Nöldeke's unusually weak criticism of Vollers. However, this does not seem to have swayed later authors who continue to cite Nöldeke's review. Rabin (1955) agrees with Nöldeke and is right to point out that, just because there were people who read the Quran without Pi $i$ ra $b$ - something clearly considered to be disturbing to those who relate these narrations - this does not mean that there was an Pi irāb-less urQuran. Conversely, however, the opposite is of course also true: that reading

5 Considering the limited accessibility to early Quranic manuscripts, or the lack of sound philological arguments for an early canonization of the text in the 19th century, it would be unfair to criticize Vollers anachronistically for not taking this into account. 
the Quran without (or with reduced) Pi $i$ räb was considered bad by third century AH authorities, a time after the activity of most of the canonical reciters had come to prominence can hardly be used as an argument that it was always considered wrong. These narrations reveal something important: Later readers and grammarians thought that any form of language could not be considered al-Sarabiyyah unless it was supplied with Pi irāb, which being the mașdar of the $\mathrm{C}$-stem of the root $\sqrt{ }$ irb literally means "to make Arabic". Therefore, there is no al-Sarabiyyah without ?ißrāb. It is not surprising that so few of the traditions seem to acknowledge a once existing form of Quranic Arabic that did not have Pi $i$ ra $b$ even if it did exist; By the time the narrations were fabricated, and certainly when the reading traditions are canonized with Ibn Muğăhid in the fourth Islamic century, the superiority of the Sarabiyyah that had Pi Gräb/tanwin was well-established and completely unassailable.

Rabin (1955) criticizes Kahle's argumentation, but misses his point. He is, of course right, that the exhortations to not read the Quran without Pi irāb, and that lahn is to be avoided does not prove that the language of the Quran was without case. I do not believe that Kahle was arguing for this. What Kahle aimed to show is that the very paradigm of reading the Quran, in this period necessitated the used of Pi $i r \bar{b} b$, any manner of reading without it, or not even following the strict model presented by the readers-cum-(proto-)grammarians, would by definition not be considered proper by the people who ended up deciding what the norms of reading the Quran would be. With the narrations brought by al-Farrā?, we are one generation removed from the canonical reader and grammarian al-Kisā?ī, as well as Sībawayhi. In fact, Rabin and Kahle seem to agree to a large extent, Rabin $(1955,27)$ says: "If, however, the language of the Koran made concessions to the literary koine, the Arabiyya, then it must needs (sic) have accepted also the case-endings, that feature which was felt to be so essential that it was called by the same word as the use of the language itself, i'rāb."

Despite what Rabin seems to think, he and Kahle are not in disagreement on this point. The disagreement stems from the fact that Rabin, and with him many others, take for granted that the language of the Quran made these concessions to the Sarabiyyah already at the time of composition during the lifetime of the prophet. Rabin takes this for granted, believing that al-Farrā?, who could not possibly conceive of the language of the Quran being anything but a language with the Pi $r a \bar{b} b$ and tanwin intact, is in fact correct in his inability to conceive of this. That assumption, however, is never substantiated in any way. The evidence of the QCT, as I see it, rather speaks against it.

Looking for evidence in the reading traditions for traces of the original language of the Quran in terms of the case system is therefore something that 
is not possible as that was not the goal of the readers. What we can recover, however, is evidence that the readers of the Quran were not trying to syllablefor-syllable transmit the pronunciation as they received it from their teacher, but instead, much like we saw in the previous chapter and chapter 3 , sought to beautify the language, and chose forms that they rationalized to be the correct pronunciation - even if that led to pseudocorrect readings. The choice of Pi $i \bar{a} \bar{b}$ by the readers was part of their job, a rational endeavour and one where different readers could and did have different intuitions and came to different solutions.

A clear place where disagreements on Pi $i$ räb frequently occur between the readers is on names of places and tribes, which may either occur as triptotes or as diptotes in the classical language. Sibawayh (III, 246-256) tells us that a name of a people may either be triptotic if it refers either to the eponymous father of a tribe or a hayy 'clan', while when it is diptotic, it refers to a qabillah 'tribe'. As Van Putten (forthcoming) shows, the distinction between hayy and qabilah does not seem to be based on any genealogical basis: both the primordial confederacy of maSadd and the famous tribe of qurayš, a tribe that belongs to maSadd are designated as hayy whereas tamim is a qabïlah. The difference between hayy and qabilah comes down to formal characteristics. In the case of a qabilah the tribe as a whole is treated as dipotic while the eponymous father is triptotic, and it can be denoted as 'sons of [eponymous father]', this constitutes a qabilah, e.g. Tamimu 'the tribe Tamìm. Tamimun 'the eponymous father of the tribe, Tamìm', banu tamimin 'sons of Tamīm, the father = the tribe Tamìm'. Such constructions cannot be formed with Qurayš, at least according to Sibawayh, and this prescription seems to be adhered to quite faithfully even today. ${ }^{6}$

For names of peoples or countries that occur in the Quran, however, the practical context to make this distinction was lacking, and as a result the readers quite plainly disagree with one another. saba? 'Shebah' occurs twice, both in

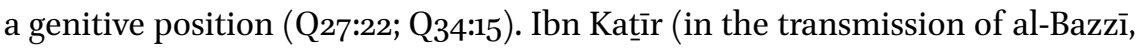
for Qunbul see § 7.1.1) and Pabū Yamr treat this name as a diptote, i.e. saba?a, whereas the other readers take it to be a triptote, saba?in. Indeed, if we look at how this distinction is explained, e.g. by Ibn Xālawayh (Huğğah, 270) he says: "whoever treats it triptotic considers it to be the name of a mountain or the name of the father of the tribe; whoever does not conjugate it, makes it to be the name of a land or a woman, so it becomes heavy from the definiteness and

6 A google search for "بنو تبميم yields 193.000 results, while a search for "بنو قريش yields only 3.840. 
femininity." In his book on what should be treated triptotic and what should be treated diptotic, al-Zağğāăğ (Mā Yanșarif, 59) presents a different opinion: "Pabu Yamr treats saba? as a diptote, so he considers it to be the name of a tribe (qabïlah)."

What should be clear from these treatments is that it is not actually known by anyone what the proper treatment of this noun should be, and rather than giving a consistent answer of what saba? refers to - which of course should be a land, the Sabaean kingdom - we get multiple solutions by the readers, seemingly not based on any real knowledge of what the conjugation should be, but rather through a rationalization from however the word should be conjugated.

This rationalization becomes even more obvious when it causes some conflict with the QCT, namely with the name of the people of Thamud. This has been discussed once before by Van Putten (forthcoming) but I will summarize the discussion here. When we look at the QCT, we find that tamüd functions as a triptote. Whenever it stands in the nominative and genitive it is spelled

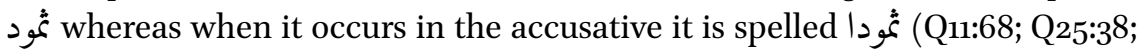

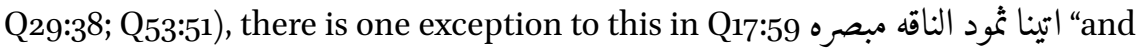
we gave Thamud the she-camel as an evident (sign)". For the latter exception there are a variety of explanations.

Despite the clear behaviour of the QCT of this word as triptotic, the canonical readers display a rather mixed treatment. The readers invariably treat the nominative as a diptote, reading tamüdu not tamüdun. The genitive is likewise treated as a diptote, reading tamūda rather than tamūdin. There is a single exception to this, which we will return to shortly. As for the accusative, most readers follow the rasm suddenly switching categories for this noun, reading it as tamūdan, but Ḥafṣ Yan Yāṣim, Ḥamzah and YaYqūb ignore the rasm and read țamūda instead. ŠuSbah Yan Yasșim only follows them in the diptotic reading in Q53:51 (Ibn al-Ǧazarī, §3298-3299). It is clear from these examples that there is somewhat of a consensus between the readers that in principle tamüd should be diptotic, but there is a difference of opinion as to whether one is free to ignore the rasm when it is unambiguous in its triptosy.

Later discussions dutifully follow the distinction as presented by Sïbawayh, and cast this discussion into terms of hayy versus qabilah, e.g. Ibn Xālawayh (hujjah, 188): "whoever treats it as triptotic, there are two opinions (as to why): one of them is: that he considers it to be the name of a hayy or a chieftain (of a tribe), and the other is that they consider it to be a fa९ulan noun from the root $t m d$, and this is a small amount of water. The one who treats it as a diptote considers it to be the name of a qabilah."

This discussion of the much earlier al-Farrā? however, is very interesting and quite different, and provides an explanation as to why his teacher al-Kisā?ī 
reads the triptotic genitive tamüdin in Q11:68 only while he reads țamüda elsewhere (al-Farrā? Måānī, II, 20):

The reciters disagreed on tamüd: among them there were those who treated it as triptotic in each case. ${ }^{7}$ As for those who treat it diptotic in this case, Muhamammad $\leftarrow$ al-Farrā? $\leftarrow$ Qays $\leftarrow$ Pabū Pisḥāq $\leftarrow$ Cabd alRaḥmān b. al-Raswad b. Yazīd al-NaxaYī $\leftarrow$ his father reports that he would never treat tamüd as a triptote in the whole Quran, and Hamzah read it thus. There are among them those who treat tamūd triptotically in the accusative because it is written with an ?alif in the whole Quran, except in one place Pātaynātamūda n-nāqata mubșirah (Q17:59), and this is what al-Kisā? $\overline{1}$ adopted, he treated it triptotically in the accusative, and diptotically in the genitive and nominative, except in one case, in HIS speech Pa-lā Pinna țamüdan kafarū rabba-hum ?a-lä bußdan li-tamüdin (Q11:68)". So, they asked him about this and he said: "it is read with the genitive of triptosy; it is ugly to have a word occur twice in two places (within the same verse) and then have them disagree [on triptosy/dipotsy], so I treated it [tamüdin $]$ as a triptote because of it being close to it [ $\underline{\operatorname{tam}} \bar{u}-$ dan]. (emphasis my own)

This extraordinary discussion reveals a view of the transmission of the readings strikingly different from how modern Islamic orthodoxy views the readings. ${ }^{8} \mathrm{Al}-$ Farrā? explains the existence of a reading being explicitly based on its spelling, rather than the writing being seen as accommodating a preexistent oral tradition. Second, he brings a report from his teacher who gives an explicitly aesthetic argument for his choice to read (Q11:68) as tamüdin rather than tamüda.

While this account of course does not prove that the Quran was once composed without $3 i$ i rāb - for that we have to rely on the philological arguments presented at the start of this section - what it does show is how readers themselves thought about their role in applying Pifrāb in recitation. Their role was not to faithfully verbatim the Pi $i \bar{r} \bar{b}$ as had been taught to them, but rather to

7 N.B. not a single one of the canonical readers reads it thus. It is reported for prominent noncanonical readers such as al-PaYmaš and Yahyā (Ibn Xālawayh muxtaṣar, 50). It is also attested in vocalized Quranic manuscripts, but seemingly only ever marked as a secondary reading: Arabe 334(d), 58r, l. 2.; Arabe 347(b), 81r, l. 4.; Cod. Guelf. 12. 11. Aug. fol., 5r, l. 4; Arabe 340(d), 64v, l. 8; Arabe 351, 147r, l. 4; Arabe 341(b), 18or, l. 1; Ms.orient.Quart.1208 (vi), 6r, l. 6; Arabe 359(c), 79r, l. 5; Arabe 325(k), 133r, l. 5; Arabe 335, 3r, l. 6; Arabe 354(c), 31r, l. 5; Arabe 35o(b), 233v, l. 3; Arabe 333(d), 74r, l. 15; Arabe 35oa, 135r, l. 2.

8 The relevance of this passage was already remarked upon by Nöldeke et al. $(2013,543)$. 
argue and rationalize why a word should have the Pi $i$ a $\bar{b}$ that they would give it. In such cases even purely aesthetic arguments such as the one cited, was apparently enough to deviate from the way their teacher taught it (Hamzah, al-Kisā?ī's direct teacher reads tamūda and li-tamüda in the relevant verse). As such the application of Pifrāb by these readers can tell us nothing at all about the use of Pi $i \bar{a} b$ of the original language of the QCT. However, given that the choice of Pifrāb was a rational endeavour explicitly based on both the rasm and aesthetic preference rather than prophetic example, it becomes quite easy to envision that the presence of this very system was not original to the text, but was rather imposed on it sometime after the standardization of the QCT by Suțān.

In some cases, we can see that to the readers certain words were no longer transparently analysable, and as a result the application of case end up being pseudocorrect. For example, the question word Payyāna 'when?' (Q7:187; Q16:21; Q27:65; Q51:12; Q75:6; Q79:42) is universally read as such by the canonical readers. This word is generally analysed as a $\mathrm{Ca} \overline{\mathrm{C}} \overline{\mathrm{C}} \mathrm{C}$ pattern of a root $\sqrt{\mathrm{i} y} / \mathrm{wn}$ whence also ?ān 'time', which subsequently receives a final $-a$ as other question words such as ?ayna or perhaps denotations of time such as yawma 'on the day' and hina 'at the time'. However, this question word is clearly a univerbation of Payya Pānin 'at which time?', where the hamzah of Pān was lost. This indeed appears to have been recognized by al-Farrā? who is quoted in the Lisān alGarab (183a) as saying:

the base [?așl] of Payyāna is ?ayya ?awānin, so they drop the vowel [ $f a-$ $x a f f a f \bar{u}]$ of the $y \bar{a}$ ? of ?ayy and removed the hamzah of ?awān, and then and then the vowelless $y \bar{a} ?$ and the $w \bar{a} w$ after it meet, so the $w \bar{a} w$ was assimilated to the $y \bar{a}$ ? , and he told this on the authority of al-Kisā?ì.

While it is probably better to derive the second part of ?ayyān from ?ān rather than ?awān,,$^{9}$ this etymology is, of course, otherwise the correct one. What is interesting in the line of reasoning, however, is that at no point the final short vowel is discussed. The explanation that is given would predict the form Payyānin rather than the now recited Payyāna. Other grammarians, perhaps for this reason, preferred different explanations for this word, but the fact

9 Al-Farrā? considered the origin (Pașl) of ?ān to also be ?awān (lisān al-\{arab, 193b). The awkward choice to argue from the form ?awān to explain this form is typical of Arabic linguistic thought, which does not like to take surface forms as input for a certain output, and instead argues from the development of a kind of platonic ideal of the word (?așl) and how that word leads to different surface forms. 
remains that this is evidently the most straightforward etymology. However, it only works if we assume that the case vowels were only applied later, and that the form that yielded Payyāna was in fact /ayy ān/, or perhaps /ayya ān/ without the final case vowel, which was subsequently later applied to the word /ayyān/ when it was no longer analysed as a compound phrase, yielding the form Payyāna rather than the expected **Payyānin.

\subsection{Lack of Final Short Vowels in the Reading Traditions}

From the examples above, it should be clear that the placement of final short vowels and tanwin in the recitation of the Quran tells us very little about what the situation was like in the original language of composition. Choosing Pi 个rāb was the duty of the reciter which could and did lead to disagreements among the readers. The fact that readers all agree that the Quran is to be read with PiSrāb is part of the ideology that gave rise to the science of recitation in the first place. Yet, from time-to-time we encounter isolated cases of words that are unexpectedly read without final short vowels.

Considering how strongly reading without final short vowels was disfavored by the grammarians early on, the very fact that such forms are transmitted at all should probably be understood as a genuine attempt of transmitting earlier forms otherwise lost to the tradition, as it is difficult to imagine how readers would have chosen to innovate transmissions without case vowels on purpose.

Of course, the existence of such forms cannot prove that the original language of the Quran lacked these final short vowels any more than their presence can - the only way to establish that is by going back to the QCT-but the existence of such transmissions does suggest that in the earliest times of the transmission of the Quran, there were transmissions going around that had forms without final short vowels. These transmissions have not come down as complete readings, but like many other cases are simply retained as singular lexical exceptions.

\subsubsection{Saba?}

While most readers either treat the name of the South Arabian kingdom of saba? as a triptote or a diptote, there is also a transmission of Ibn Katîr through the canonical transmitter Qunbul (a teacher of Ibn Muğāhid) who simply read it without any Pi $i r a \bar{b} b$, i.e. saba? rather than saba?a or saba?in in Q27:22 and Q34:15 (Ibn al-Ǧazarī, §3803). Ibn Muğāhid (480) considered this Pi reading a mistake (wa-huwa wahm), affirming that the transmission of al-Bazzì is the correct one, but despite that he also brings a single strand transmission 
independent of Qunbul that likewise transmits this ?i b. Muhammad b. Subayd aḷāh b. Pabī yazīd $\leftarrow$ Šibl $\leftarrow$ Ibn Kațīr). It is interesting to note that Al-Dānī seems disturbed enough by this, even in his al-Taysīr - a book that normally does not spend much time explaining certain forms - that he feels it is necessary to qualify why Qunbul would read it as such, saying that it is "with the intention (for it to be) the pausal form" (Salā niyyati l-waqf) (AlDānì taysìr, 27).

This caseless transmission presents a problem for scholars who wish to explain this form, as the grammatical framework that the grammarians have set up do not normally allow for the absence of any inflection in the middle of a verse, and as such only post hoc explanations are adduced. For example, Ibn Xālawayh (Huğğah, 270) says: "whoever quiesces the hamzah would say: This noun is feminine, and that is heavier than masculine; it is definite, and that is heavier than indefinite; it is hamzated and that is heavier than not having a hamzah, as these features come together in the noun that we have mentioned, the heaviness is lessened by quiescence of the final short vowel."

\subsubsection{As-sayyi?}

The noun as-sayyi? السيا 10 occurs in its definite form twice in the same verse (Q35:43). Hamzah reads the first occurrence without Ti $\{r a \bar{b}$, i.e. as-sayyi?, while the second one is read as as-sayyi?u (Ibn al-Ǧazarī, § 3991). It should be noted here that one cannot argue that this is a pausal pronunciation, as Hamzah drops the hamzah in pause, i.e. as-sayyi, a distinction specifically commented on with regard to this verse by al-Dānī (taysīr, 182 f.)

Ibn Xālawayh (Hujjah, 297) cannot use the same argumentation why this form is caseless as he did for saba?, as this noun is not feminine. Instead, he suggests that it was "lightened" because of the meeting of two kasrahs in a row. He likens this to Pabū Yamr's reading of bāri?i-kum as bāri?-kum (Q2:54; see § 7.2.5). This explanation is, of course, ad hoc as Hamzah does not read ba ari?i-kum without the case vowel, nor min šățiî l-wād (Q28:30) which is more comparable in terms of phonetic context.

\subsubsection{Mahyyā-y}

Nāfí and Pabū GaSfar are unique in reading محياى (Q6:162) as mahyā-y (Qālūn; Pabū Ğaffar) mahyyǟy (Warš) rather than mahyā-ya (Ibn al-Ǧazarī, § 2513). This is irregular within these readings. Other cases of nouns ending in ?alif maq-

10 The spelling سيا rather than the CE سيى is the standard spelling in early manuscripts (van Putten 2018, 115). 
șürah followed by the 1sg. ending simply have -ya, e.g. هداى (Q2:38) is hudā-ya (Qālūn; Pabū ĞaSfar) or hudē̄ya (Warš).

\subsubsection{Yä-bunay}

There is disagreement among the readers on how to read يبي 'o my son' in its six attestations (Q11:42; Q12:5; Q31:13, 16, 17; Q37:102) (Ibn al-Ğazarī, § 3291). Hafș San fāșim read it as yā-bunay-ya whenever it occurred. Šu Sbah Yan Yāșim follows him in Q13:13 and Q31:17 only. In all other cases he read $y \bar{a}$-bunayy $i$ with the more typical shortened vocative 1sg. ending $-i$ as also found in يب $y \bar{a}-$ ?abati 'o my father', يرية yâ-rabb-i 'o my lord', يقوم $y \bar{a}-q a w m-i$ 'o my people'. All other readers follow the reading $y \bar{a}$-bunayy- $i$ instead.

For Ibn Katīir, there is an exception, he specifically reads Q31:13 as yā-bunay, without final $-i$, nor with gemination of the final consonant. It might be that it simply means 'O son!' rather than 'O my son', but even in that case one would have expected yā-bunayyu rather than no case vowel at all. This is therefore clearly an uninflected form in Ibn Katîir's reading. This ?ißrābless form occurs again in Q31:17, which is read as yā-bunay by Qunbul whereas Ibn Katīir's other canonical transmitter, Al-Bazzī reads it as yā-bunay-ya, while he usually read $y \bar{a}$-bunayy-i elsewhere.

\subsubsection{YartaS/nartaS}

An interesting case of the loss of final short vowels is بعi2:12). This is read by most readers as a jussive yarta $\{$ or narta , and is taken to be from a root $\sqrt{r} t \uparrow$ which in this G-stem supposedly means 'to graze' and figuratively 'to revel, indulge freely (in)'. However, several readers read it as the jussive Gt-stem of raS̄a 'to pasture', i.e. nartaSi (Ibn Kațīr) or yartaSi (Abū ĞaSfar and NāfiY). ${ }^{11}$

irta $\bar{a} \bar{a}$ 'to graze; pasture' and rata $\uparrow a$ 'to graze; to revel' are obviously related and the latter must be considered a reanalysis of the former. This, however, is only possible from a stage of the language where final short vowels were lost. In Quranic Arabic, final long $\bar{\imath}$ is lost completely in pause, and such shortened forms are occasionally also used outside of pause (van Putten and Stokes 2018, $156 \mathrm{ff}$.). The imperfective of irta $\bar{a}$ would thus be yarta $\uparrow$ or $y a r t a \uparrow$ and in pause exclusively yarta@\#. The jussive form would always be yarta . These shortened forms without final short vowels in the prefix conjugation look identical to the prefix conjugation of a verb derived from a root $\sqrt{r} t \uparrow$. The root $\sqrt{r} t \uparrow$ must be

11 Ibn Muǧăhid does not mention this disagreement among the readers at all. Al-Dānī (taysīr, 128) reports it. He says that most readers read narta؟; That Yāṣim, Al-Kisā?ī and Ḥamzah and NāfiS read yartaS and that the Ibn Katīir and Nāfí read it with a final $i$, i.e. nartaSi and yartaSi respectively. Abū ĞaSfar also reads it with the final $i$ (Ibn al-Ğazarī, 293). 
the result of a reanalysis of the prefix conjugation yarta , which allowed for a reanalysis that is only readily possible in a variety of Arabic that has lost final short vowels. ${ }^{12}$ We must therefore see the root $\sqrt{r t} \uparrow$ as an artifact of grammatical thought of the Arab grammarians who were confronted with the reading yartaS lacking final short vowels - a form which would be incorrect in the Arabic which retained final short vowels - unless it was the jussive of a nonexistent root $\sqrt{ } r t$. From there a new verb with this root $\sqrt{r} t\}$ was coined. This reanalysis is unlikely to have happened in a variety that had full ?i iräb present, as the jussive yarta $i$ is not homophonous to *yartaS.

\subsubsection{Tatran, tatrā, tatrē}

An example where the readers show disagreement on whether a noun should have tanwin or not can be found in Iت 'one after another, in succession' (Q23:44) which is read by Ibn Katîir, Pabū Yamr and Pabū ĞaSfar as tatran, whereas the rest reads it as tatrā or tatrē, depending on whether they apply Pimālah to the $-\bar{a}$ feminine suffix (Ibn al-Ğazarī, §369o). Traditionally this word is interpreted as either a CaCC derivation of watira 'to string' or a CaCCā derivation of the same (Ibn Xālawayh Huğğah, 257). The initial $t$ is explained as an alternation of $w$ and $t$ in the way that we see it in turāt 'inheritance' from warita 'to inherit', but such an explanation in either case is not particularly attractive. This $w / t$-alternation is otherwise only found in in tuCāC and tuCaCah (e.g. tuxamah 'indigestion') derivations from I-w verbs (Fischer 2002, § 240.3). Whatever the actual derivation of this noun, it is clear that because of the obscurity of this hapax legomenon and its derivation, readers could not agree whether the word was to have tanwin or not, and hence we are confronted with both options. ${ }^{13}$

\subsubsection{Tựār}

تضار (Q2:233) is variously read by the canonical seven as tuḍarru (Ibn Kațīr, Pabù Samr, YaYqūb, Ibn Yāmir) or tuḍārra (Nāfị, Ḥaf̣̣ Yan Yāṣim, Ḥamzah, al-Kisā?ī, Xalaf). However, Abū ĞaSfar reads it in a completely i $i r a ̄ b$-less form tuḍār. He also read يضار (Q2:282) without Pi يrāb.14 (Ibn al-Ǧazarī, § 2774).

12 The root $\sqrt{r} t \uparrow$ also lacks Semitic cognates, unlike, $r a \uparrow \bar{a}$ which is easily reconstructible for

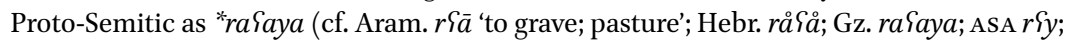
Akk. re?û).

13 See also Nöldeke et al. (2013, 417, n. 184) who are equally skeptical about the derivation.

14 Moreover, both with degemination of the final consonant, a feature reported for Middle Arabic (Blau 2002, §10). 


\subsubsection{The 3sg.m. Suffix $-h$}

A striking category of words that lack expected final (long!) vowels in the Quranic reading traditions are the final weak verbs that occur in the apocopate or imperative followed by the third person masculine clitic pronoun $-h \bar{u} /-h \bar{\imath}$. Verbs of this type occur sixteen times in the Quran, and every single one of them is reported among at least one of the canonical readers without the expected final vowel, and occasionally with a short form -hi/hu rather than $-h \bar{\imath} / h \bar{u}$. There is a good amount of disagreement among different works on the Qirā?āt, for simplicity's sake, the following table is based on Ibn al-Ğazarī

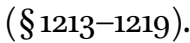

\begin{tabular}{|c|c|c|c|c|c|c|c|c|c|}
\hline & $\mathrm{IK} / \mathrm{K} / \mathrm{X}$ & Wšs & IA & Qā & $\mathrm{Y}$ & $\mathrm{AJ}$ & AA & $\mathrm{H} / \check{\mathrm{S}}$ & Ḥṣ \\
\hline يوده & -hī & $-h \bar{i}$ & -hī, -hi, -h & -hi & -hi & $-h(-h i)$ & $-h$ & $-h$ & -hī \\
\hline يوده Q3:75 & -hī & $-h \bar{i}$ & -hī, -hi, -h & -hi & -hi & $-\mathrm{h}(-\mathrm{hi})$ & $-\mathrm{h}$ & $-\mathrm{h}$ & -hī \\
\hline Qوته & -hī & hī & $-h \bar{i},-h i,-h$ & -hi & -hi & $-h(-h i)$ & $-h$ & $-h$ & -hī \\
\hline ن3:145 نوته & -hī & hī & -hī, -hi, -h & -hi & -hi & $-\mathrm{h}(-\mathrm{hi})$ & $-\mathrm{h}$ & $-\mathrm{h}$ & -hī \\
\hline نوله Q4:115 & -hī & -hī & -hī, -hi, -h & $-h i$ & -hi & $-h(-h i)$ & $-\mathrm{h}$ & $-h$ & -hī \\
\hline نصله Q4:115 & -hī & $-h \bar{i}$ & -hī, -hi, -h & -hi & -hi & $-\mathrm{h}(-\mathrm{hi})$ & $-\mathrm{h}$ & $-\mathrm{h}$ & -hī \\
\hline نوته Q42:20 & -hī & $-h \bar{i}$ & -hī, -hi, -h & -hi & -hi & $-h(-h i)$ & $-\mathrm{h}$ & $-h$ & -hī \\
\hline Q27:28 فالقه & -hī & $-h \bar{i}$ & $-h \bar{i},-h i,-h$ & -hi & -hi & $-\mathrm{h}(-\mathrm{hi})$ & $-h$ & $-\mathrm{h}$ & $-\mathrm{h}$ \\
\hline يتقه Q24:52 & -hī & -hī & -hī, -hi, -h & -hi & -hi & -h, -hi, -hī & $-\mathrm{h}$ & -h, -hī & -q-hi \\
\hline Q20:75 ياته & -hī & -hī & -hī & -hi (-hī) & -hi & -hī & -h, -hī & -hī & -hī \\
\hline ارجه Q7:111 & -Phū/-hī & -hī & $-\mathrm{Phū} / \mathrm{i}$ & -hi & $-? h u$ & -hi, -hī & $-?-h u$ & $-h$ & $-\mathrm{h}$ \\
\hline ارجه Q26:36 & -?hū/-hī & -hī & $-P h \bar{u} / \mathrm{i}$ & -hi & $-? h u$ & -hi, -hī & -P-hū & $-h$ & $-\mathrm{h}$ \\
\hline يرضه Q39:7 & -hū & -hu & $-h \bar{u},-h u,-h$ & -hu & -hu & $-\mathrm{h}(-\mathrm{hu})$ & -h, -hu, -hū & $-h,-h u$ & -hu \\
\hline يره Q990: & $-h \bar{u}$ & $-h \bar{u}$ & -hū & $-h \bar{u}$ & -hu, -hū & -hu, hū & -hū & $-h \bar{u}$ & -hū \\
\hline يره Q99:7 & -hū & -hū & $-h \bar{u},-h$ & $-h \bar{u}$ & -hu, -hū & $-h,-h u,-h u ̄$ & -hū & -hū & -hū \\
\hline يره Q99:8 & -hū & -hū & $-h \bar{u},-h$ & -hū & -hu, -hū & -h, -hu, -hū & -hū & $-h \bar{u}$ & -hū \\
\hline
\end{tabular}


It is possible to make several generalizations on the basis of this table. First, al-Kisā?ì̄, Xalaf and Ibn Katīir do not show any unusual behaviour in these verbs, and simply follow their general rules of the pronouns. Warš Yan Nāfi follows them almost completely, only making an exception at yarda-hu.

YaYqūb consistently treats these apocopates/imperatives that have a final $-i$ as if they ended in final $-\bar{l}$, and therefore vowel length disharmony is triggered. This behaviour is reminiscent of another part of his reading that we have discussed earlier (§ 3.6.3): Yåqūb does not harmonize the third person plural suffix -hum to -him if ay or $\bar{\iota}$ precede. Rawh Yan YaYqūb likewise treats apocopates as if they ended in final $-\bar{\imath}$ and does not apply vowel harmony either. This parallel is unlikely to be a coincidence.

Qālūn Yan Nāfiৎ, like YaYqūb consistently has a short pronominal form after apocopates that end in -hi. Unlike YaYqūb, Qālūn has no other examples where he seems to treat apocopate $-i$ as if it were $\bar{\imath}$. For Qālūn with apocopates that end in $-a$ length disharmony does not get triggered either, although there are transmissions for Yaqqūb that lack it too, and thus we see yara-hü (Q90:7; Q99:7, 8). But for yarda-hu (Q39:7), like Warš he has a short vowel.

Taking the imperfect as the basis of the vowel length disharmony rule is indeed how it is explained in Huğğah literature, Ibn Xālawayh (Huğğah, 111) for example says: "those who pronounce the vowel (of $-h V$ ) short take the base (?așl) of it to be yuraddi-hi, and then the $y \bar{a}$ ? disappears because of it being an apocopate, and the shortened vowel remains because of what its base (?așl) was."

This type of reading however, can hardly be understood as the outcome of natural language. The rule of vowel disharmony not being affected by the shortening of the $\bar{\imath}$ is imaginable if the vowel-length disharmony of the pronominal suffix predates the shortening of the vowel in the apocopate. The phonological process would then have been phonologized due to this development. However, the order of development is reversed: apocopate forms of the verb go at least as far back as Proto-West-Semitic, evidence of them being present, for example, in Hebrew (yibnī 'he builds' way-yiben 'and he built' < *yabniyu, *yabni), whereas it seems clear that the vowel length disharmony is a (Classical) Arabic internal development. The use of the short form of the pronoun, therefore should be considered an explicit grammarian rationalization from the view that apocopates are shortened forms of the imperfective, rather than a natural outcome of the language.

The vowelless forms as found in the readings of Šưbah, Hamzah, ?abū famr and Pabū Ğaffar rather appear as overzealous application of the grammatical rules of apocopation. All of them more-or-less consistently have no vowel on the pronoun at all on the apocopates that end in in $-i$. 
What this seems to stem from is that all of these readers start with a surface imperfective form, e.g. yattaqi-hi, and subsequently apply the rule to make an apocopate form to both parts of the word, shortening final $-\bar{\imath}$ and dropping final -i. Indeed al-Farrā? (Maৎānī, I, 224) was aware that some readers seem to view it as such, although he considers it a mistake:

Al-Paimaš and Yāșim used to drop the vowel of the hā? in yu?addi-h, yuwalli-h mā tawallī, Parği-h wa-Paxā-hu, xayran yara-h, ${ }^{15}$ šarran yara- $h$. And there are two ways of viewing this for them [wa-fihi la-huma madha$b \bar{a} n]$ : One of these is that the people considered it to be the apocopate of the $h \bar{a}$ ?, in fact [what is apocopated] is in front of the $h \bar{a}$ ? . So, this-if it is the case that they supposed that—is a mistake.

The second option that al-Farrā? presents, however, is not particularly convincing as an explanation of these forms. He gives cases where Arabs may pronounce the pronoun as $-h$, but none of the cases he cites account for the environment in which we see this behaviour:

As for the other option, either there are among the Arabs those who apocopate the $h \bar{a}$ ? when there is a short vowel before it. So, they say: darabtu- $h$ darban šadìd $\bar{a}$, or one removes from the $h \bar{a} ?$ the raff of its base as is the case with ra?aytum and ?antum. Do you not see that the mim is quiesced while its base is raff [In al-Farrā?'s framework, the base of these words is ra?aytumū and ?antumū]?

$\mathrm{Al}$-Farrā? is clearly bothered by the first explanation, as it evidently stems from ignorance of the grammatical model the grammarians-him included-rely upon, but it is also evidently less ad hoc than his other option, which does not explain at all why these shortened formed only occur specifically with the imperative and apocopate of III- $y / w$ verbs.

It might be possible that the origin of this overzealous application of this rule may have to do with transmissions that originally lacked final short vowels. In the nascent period of grammatical theory-readers like al-3aimaš (d. 148) and Sāșim (d. 127) predate Sībawayh by one to two generations-it seems possible that in other contexts the application of the apocopation rules was less

15 This reading has not come down to us through transmissions of the canonical readers. Al-Farrā? usually appears to report Yāṣim's reading from ŠuSbah. 
ambiguous than with the final weak verbs, and therefore these were classicized properly, whereas the final weak verbs went under the radar and their quiescent forms were retained.

There are some irregularities among the readers with fully vowelless forms, but Ibn Muğāhid (211f.) reports a zero vowel for every form for Hamzah $\rightarrow$ alKisā?ī $\rightarrow$ al-Farrāê and Yāṣim $\rightarrow$ ŠuSbah $\rightarrow$ Yahyyā b. Pādam. The latter is also reported by al-Farrā? in his Maৎāni and is likely to have been the original transmission, considering how close al-Farrā? is to the source. There do not seem to be transmissions on Pabū Yamr's authority with short vowels however. Al-Dānī ( $\breve{a} \bar{a} m i \varsigma, 457)$, however, does bring reports of the expected form yara-h for alDūrī $\leftarrow$ Pabū Yamr.

An obvious explanation for the exceptional status of the forms yara-hu is that two of the three cases stand in a rhyme position. It is likely that the original transmission simply transmitted these forms in their pausal for yara$h$ - the natural pronunciation in this position - and only on further inquiry by later transmitters, were non-pausal forms invented, this time not following the overzealous apocopation rule of the early readers, but rather one that simply followed the Classical Arabic rules, which would generate yara-hü, the one other case of yara-hū subsequently followed suit.

A truly baffling transmission is the reading of Hafṣ San Sāșim of يتقه 'fears him' $\left(\mathrm{Q}_{24: 52}\right)$. While the other readers have yattaqi- $h(i / \bar{\imath})$, as one would expect, Hafs drops the short vowel of the jussive altogether, while retaining a short harmonized form of the pronoun. There does not seem to be an obvious way to account for such a form from Classical Arabic grammar. The most obvious explanation is that it comes from an underlying form yattaq- $h$ where the final $i$ is epenthetic to avoid a word-final two consonant cluster-something avoided in Classical Arabic. This is the explanation given by Ibn Xālawayh (Huğğah, 263), the reason why the apocopate would have lost the final $i$-vowel in this position, however, can only be explained by deriving it from a variety where at least in some positions the apocopate of final weak verbs lost the final $-i$, presumably a dialect which (at least) lost the final short vowel $-i,{ }^{16}$ which was then analogically spread to non-final position. Indeed, Ibn Xālawayh seems to attest the existence of such a form, citing a line of poetry that has the form yattaq.

All the specific complexities and disagreements of these forms aside, it is clear that there was great disagreement on how to treat these cases, something that is difficult to imagine if the Quran had been transmitted in its predictable

16 Blau $(1977,15$ f.) seems to suggest that the Meccan dialect would have been such an old Arabic dialect. 
classical form. Both the forms with long vowels $-h \bar{u} / \bar{\imath}$ and $-h u / i$ can be understood as later grammarian intervention, especially the latter being dependent on specific grammatical analysis that cannot be thought to have existed before the rise of Arabic grammatical theory. The $-h$ forms, however, are clearly the lectio difficilior here. While it can certainly be envisioned that these too were generated by nascent grammatical theory with an overapplication of apocopation rules, it also seems possible that simply original transmissions without final short vowels shine through here instead.

\subsubsection{The Mysterious Letters}

A special case of words being unexpectedly pronounced without any form of Pi Y $r \bar{b} b$ in the reading traditions are the mysterious letters at the beginning of Sūrahs. The names of the letters in Classical Arabic are simply inflected, just like any other noun in the language, and in principle there is no reason why الم would not be read as Palifun lämun mimun, but instead all of the letters are universally read without their inflectional endings. This could perhaps be understood as pausal pronunciations of these letters, and this is how Rabū Ğąfar treats them, who introduces a pause after every single mysterious letter (Ibn al-Ğazarī, § 1592). The rest of the readers, however simply treat these words as if they are nouns that lack all inflection, and pronounce them in context. As such, these letters may even undergo assimilation with each other, and the following words, e.g. Q26:1, Q28:1 طسم is pronounced with assimilation of the $n$ of $\sin$ to the $m$ of the following word by most readers (see Ibn al-Ğazarī, § 1907-1917 for a full discussion).

The form of the mysterious letters is fairly easy to understand from a situation that started out as lacking inflectional endings, which were classicized. As these mysterious letters have no obvious syntactical function, it is difficult to classicize these into an inflectional paradigm. The inverse, however, is more difficult to understand. There is no reason why the mysterious letters would be uninflected, if the base language of the Quran was inflected.

\subsection{Was Pabū Yamr's Reading an Rifrāb-less Reading?}

The most recent work on the potential absence of case in a reading tradition of the Quran, and by extension the possible caselessness of an Ur-Quran was put forward by Jonathan Owens (2006, 119-136), who argues that the reading of Pabu Yamr originally represented a reading tradition that did not inflect for case, and was only later classicized to have case. This is essentially a continuation and further elaboration of Vollers' (1906) original theory concerning this 
topic, bringing to bear modern linguistic insights in understanding Pabū Yamr's phenomenon on 'Major Assimilation' (al-Pidjām al-kabìr), i.e. assimilation of consonants across word boundaries, even when there is an intervening short vowel. If Owens' argument is correct, it would mean that it is not just the QCT (as argued by van Putten and Stokes 2018), but even one of its canonical readings that originally lacked the case system of Classical Arabic. However, the arguments put forward by Owens are not quite convincing, as we will see in the following sections. The major assimilation of Pabu Yamr is not as alien to the model of the grammarians as Owens makes it out to be, and I will show that Pabū Yamr's reading can only be understood if we assume the underlying presence of some kind of case system as part of his system.

\subsubsection{Al-Pid $\dot{g} a \bar{m}$ al-kabīr}

All reading traditions of the Quran have some amount of assimilation across word boundaries, but this usually only happens with tanwin or consonants that are not followed by a vowel. Pabu Samr's reading is unique in that it frequently occurs across word boundaries when there is an intervening short vowel, yielding forms such as: qāla rabbu-kum $\rightarrow$ qārrabbukum (Owens 2006, 127).

Such assimilations take place when either the final consonant of the first word and the first consonant of the second word are identical, or close in terms of place of articulation. Owens represents this Major Assimilation through two rules, where $\mathrm{C}_{\mathrm{a}}$ is an 'assimilatable' consonant:

1. $\mathrm{C}_{1 \mathrm{a}} \breve{v} \# \mathrm{C}_{2 \mathrm{a}} \rightarrow \mathrm{C}_{1 \mathrm{a}} \# \mathrm{C}_{2 \mathrm{a}}$

2. $\mathrm{C}_{1 \mathrm{a}} \# \mathrm{C}_{2 \mathrm{a}} \rightarrow \mathrm{C}_{2 \mathrm{a}} \mathrm{C}_{2 \mathrm{a}}$

He considers these rules "linguistically odd", as rule 2 cannot precede rule 1 , but rule 1 only applies when 2 also applies (Owens 2006,130$).{ }^{17}$ As such, rule 1 seems to anticipate rule number 2 before it has taken place. The dependency of rule 2 on rule 1 prompts Owens to suggest that rule 1 was not originally operative, and that the base form simply lacked the case vowels that are elided through this rule. Later classicization would then have included these case vowels into the reading, wherever assimilation did not prevent this from happening.

17 While the kind of 'permeability' of final vowels for assimilation is certainly rare, the Awadhi language (and Eastern-Hindi language, spoken in India and Nepal) provides a strikingly close parallel to ?abū Yamr's major assimilation. Awadhi as three short high vowels $/ \mathrm{i} /, / \mathrm{u} /$ and $/ \mathrm{e} /$, which are devoiced in word-final position. When these vowels stand between two consonants with the same place of articulation they are syncopated. Depending on the consonants that come to stand next to each other, this may subse-

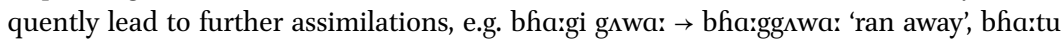
da:rio $\rightarrow$ bfa:dda:rio 'rice and pulse', csli difas $\rightarrow$ csldifia: 'started' (Saksena 1937, 94). I thank Hamza Khwaja for providing me with this reference. 
I have trouble seeing why the rules as formulated by Owens are "linguistically odd". Major assimilation of this type occurs frequently in the Quran and its readings-albeit irregularly, and contrary to Owens' $(2006,130)$ claim, it is covered quite extensively by Sibawayh. Returning back to the assimilation rules 1 and 2, Owens says: "For Sibawayh, then type (8a) [rule 1, MvP] applies within words, and between words only when the two consonants are identical; (8b) [rule 2, MvP] applies across word boundaries, with an input in which two consonants abut one another." (Owens 2006, 131). For the example of the assimilation happening within a word, Owens cites yaqtatil $\rightarrow$ yaqittil. However, his claim that such assimilations are only described by Sibawayh when they involve identical consonants, is incorrect. In fact, on the very page that Owens cites for the assimilation yaqtatil $\rightarrow$ yaqittil (Sïbawayh in the Derenbourg edition, vol. II, 459) there are three examples of this assimilation where the assimilation happens within a word where the two consonants are not identical. Sībawayh cites here irtadafa $\rightarrow$ raddafa, al-Ḥasan al-Bașrīs reading ixtațafa $\rightarrow$ Pilla man xattafa l-xatfah $\left(\mathrm{Q}_{37}: 10\right) ;{ }^{18}$ and a reading of the people of Mecca murtadifina $\rightarrow$ muruddifina (Q8:9). ${ }^{19}$ This is far from the only time that Sïbawayh discusses this kind of development happening within word-boundaries. Other examples he cites are: yatasammåūna $\rightarrow$ lā yassama IV, 463), ${ }^{20}$ talätata darāhima/Paflusin $\rightarrow$ țalāttu (Sïbawayh IV, 464), yatașāliḥa $\rightarrow$ yașsâliḥa (Sïbawayh IV, 467), ${ }^{21}$ yaxtașimūna $\rightarrow$ yaxașșimūna $\left(\mathrm{Q}_{3} 6: 49\right)$, yatațawwa@ūna $\rightarrow$ yațtawwa others), yatațayyarū $\rightarrow$ yațtayyarū bi-mūsā (Q7:131), tațawwaSa $\rightarrow$ ițtawwaSa,

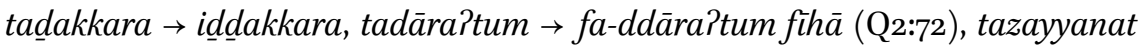
$\rightarrow$ wa-zzayyanat (Q10:24), tazayyunan $\rightarrow$ izzayyunan, taddāru?an $\rightarrow$ iddāru?an, tațayyarnā $\rightarrow$ itțayarnā bika (Q27:47), also the acceptability of yahtadūna $\rightarrow$ yahiddūna is implied, though not explicitly mentioned ${ }^{22}$ (Sībawayh IV, 474475).

Admittedly, Sībawayh cites very few examples of major assimilation of dissimilar consonats across word boundaries, although I have found one example.

18 Recorded by Ibn Xālawayh (muxtașar, 127) as xițtịfa for al-Ḥasan, Qatādah and Yīsā.

19 The Meccan Ibn Katīir simply reads murdifina (Ibn al-Ğazarī, § 3169).

20 He is citing Q37:8 لا يسمعون here, which is read by Ḥaș Yan Yāṣim, Hamzah, al-Kisārī and Xalaf as an assimilated tD-stem, where the rest reads it as yasmaৎūna (Ibn al-Ǧazarī $\S 4030$ ). His comments that "unassimilated is proper Arabic" should perhaps be seen as a subtle jab at the Kufans.

21 Sībawayh cites Q4:128 يصلح here, which is read by most readers as yașșālihāa, only the four Kufans read yuṣlị̂a (Ibn al-Ğazarī § 2961).

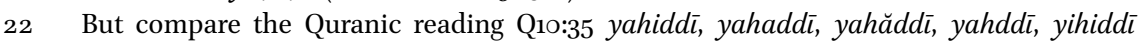
(besides yahd̄̄) (Ibn al-Ǧazarī § 3256$)$. 
Sïbawayh (IV, 450) cites the assimilation of $S$ to $h$, in which case both consonants are shifted to $h$. Here he cites both word-internal and word-external examples maSa-hum 'with them' $\rightarrow$ mahhum and maSa hä?ulä?i 'with these' $\rightarrow$

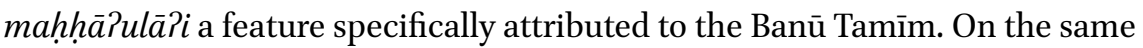
page he also cites a line of poetry which underwent mashi- $h \bar{\imath}$ ' his anointment' $\rightarrow$ mashḥ̂i ( $\rightarrow$ mashị̂?).

The absence of extensive assimilation of this type across word-boundaries, however, does not help Owens' argument. Owens' main objection to the possibility that such an assimilation took place against word boundaries is that it does not take place word-internally, the above examples should make abundantly clear that they do. Where across word-boundaries we may doubt whether the underlying form had an intervening vowel, we cannot make this case for the word-internal cases. So, whether this assimilation across vowel is "linguistically odd" or not, it is evident that it is happening, even in wordinternal position, and therefore it is difficult to invoke this intuition as an argument against the presence of intervening short vowels.

Nöldeke was therefore right to dismiss Vollers' use of major assimilation as evidence for the complete absence of Pi $i r a \bar{b}$, and Owens has not made a compelling case against it. Moreover, the presence of clear cases of word-internal major assimilation in the QCT (there are many more examples besides those that Sïbawayh cites, see also Appendix A.3.5) prove that we are not dealing with Sībawayh's grammatical invention, but with actually attested linguistic forms.

While major assimilation in ?abū Yamr's reading cannot serve as evidence for the absence of case vowels, it certainly does not prove that they existed either. However, there are several other features of ?abū Yamr's reading that clearly require us to presuppose the presence of case vowels, which we will look at in more detail in the following sections.

\subsubsection{I-umlaut}

Many other aspects of Pabu Samr's reading are dependent upon the presence of case vowels, as admitted by Owens himself (Owens 2006, 132). One of these is the Pimālah of any stem-final $\bar{a} r$ (see $\$ 3.6 .2) .{ }^{23}$ Whenever stem-final $\bar{a} r$ is followed by $i$ (but not $\bar{\imath}),{ }^{24}$ e.g. an-nāri $>$ an-nēri $(\mathrm{Q} 2: 39)$; kaffārin $>$ kaffēerin

23 Note that this means that stem internal āri sequences do not undergo Pimālah, so bāridun $\left(\mathrm{Q}_{3} 8: 42\right)$ is not read with Pimālah. It explicitly applies only if the $r$ is the third root consonant (see also $§ 3.6 .2$ ).

24 There is one verse specific exception, on which thransmitters of ?abū Yamr disagreed: alğāri (Q4:36, both occurrences) (Ibn al-Ǧazarī, § 2050). 
(Q2:276). This $i$-umlaut operates even if al-Pidgām al-kabir causes the triggering kasrah to be dropped hence Salā l-kuffāri ruhamā̄iu > Salalkuffērruhamāîu (Q48:29) (Ibn al-Ğazarī, §1192). The underlying phonological representation therefore needs the presence of the case vowel, despite its absence in the surface form.

\subsubsection{Rawm and ?išmām}

Owens (2006, 132 ff.) suggests that the use of 7išmām and rawm in Pabū Yamr's reading point to more examples of reduced case distinction. However, they actually show the opposite. Owens' position seems to stem from a misunderstanding of his sources. The first misunderstanding seems to be what these two terms mean and the second is where they occur. Owens labels rawm as labialization' and Pišmām as 'fronting and rounding'. This is incorrect. ${ }^{25}$ It is helpful to cite Pabū Yamr al-Dānī's description of the two concepts here, which I find

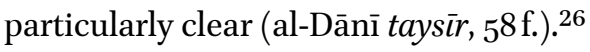

As for the meaning of rawm: it is when you weaken the sound of the vowel until it has gone almost completely, so that you will hear it as a concealed sound. A blind person can perceive it with his sense of hearing.

As for the meaning of Pišmām: you bunch up your lips after the, originally, vowelless (final) letter. A blind person cannot perceive that information, because it is seen with the eye and nothing else.

In other words: rawm denotes ultra-short vowels while Pišmām is labialization, and indeed this is how it is taught today. It is true that ?abu Yamr has the option to use rawm and Pišmām, but it is incorrect that these neutralize short high vowels. Again, it pays to look at the descriptions of the Qirā?āt works, al-Dānī continues:

25 Confusion on this topic is understandable, the terminology has been used in different ways by different grammarians. Ibn al-Ğazarī for example reports that the Kufan grammarians used the two terms in the opposite manner from the general discussion (III, 1863), and that the use of the term rawm had a slightly different meaning amongst the grammarians than among the readers (Ibn al-Ǧazarī, III, 1878; § 2295). Needless to say, when discussing the terminology in the context of ?abū Yamr's reading, we should be sticking to the way that the reciters use it. As far as can be gleaned from Sībawayh's (IV, $168 \mathrm{ff}$.) description, it seems to mostly agree with what the readers say (except for him also fathah can undergo rawm). While neither rawm and iišmām is explicitly defined, it is pointed out that ?išmām only applies with dammah.

26 But other descriptions leave no doubt that they are in fact the same, there is no difference of opinion between Ibn al-Ǧazarī $(\S 2277, \S 2278)$ and al-Dānī here. 
So as for the rawm, it is applied by the readers with the raff, dammah, garr or kasrah, and they do not employ it for the nașb or fath because of their lightness.

As for Pišmām, it only occurs for the rafৎ and dammah, and nothing else.

In other words when rawm is applied, it is to $u$ and $i$ and there is, in fact, no neutralization: $u$ is articulated as $\breve{u}$ and $i$ as $\breve{\iota}$. As for Pišmām it is sensibly only used for the nominative and imperfect. When a reciter decides to recite with rawm or Pišmām, they are applied whenever the context allows, while, when the context does not, the recitation resorts back to full assimilation. So rather than neutralizing distinctions it in fact creates more distinctions not present if a reciter of ?abū Samr's reading opts for no ?išmām or rawm and simply adhered to Pidjām only. It should also be added that, when Pabū Yamr opts for rawm, the consonants are not actually assimilated. Keeping this in mind, Owens' (2006, 133) example qaala rabb-u-kum $\rightarrow{ }^{* *}$ qaarw rabbukum does not occur at all. Even when opting to include Pišmām or rawm in recitation this would always be pronounced with assimilation and no labialization: qa arrabbukum. The table below summarizes the outcomes of these three processes in his recitation.

\begin{tabular}{|c|c|c|c|c|c|}
\hline & Input & & Pidġām & With Pišmām & With rawm \\
\hline $\mathrm{C}_{\mathrm{a}} \mathrm{aC}_{\mathrm{a}}$ & qāla rabbu-kum & $\rightarrow$ & qārrabbukum ${ }^{27}$ & qārrabbukum & qārrabbukum \\
\hline $\mathrm{C}_{\mathrm{a}} \mathrm{iC}_{\mathrm{a}}$ & al-\{umuri li-kaylā & $\rightarrow$ & alৎumullikaylā & alsumullikaylā & alSumurĭ likaylā \\
\hline $\mathrm{C}_{\mathrm{a}} \mathrm{uC}_{\mathrm{a}}$ & yaškuru li-nafsi-hī & $\rightarrow$ & yaškullinafsihī & yaškulwlinafsihī & yaškurŭ linafsih̄̄ \\
\hline
\end{tabular}

Owens' confusion about the terminology here is understandable, as Ibn Muğāhid (156) uses the verb ?ašamma in a non-technical way in some places of his discussion. For example, on the discussion of the words yufallimu-hum (Q2:129) and yalfanu-hum (Q2:159) he says that, in a transmission of Salī alHāšimī, Pabū Samr "used to give taste (yušimmu) to the mìm of yu fallimu-hum and the nūn of yalfanu-hum - both before the hâ? - of damm without full pronunciation $(? i \bar{s} b \bar{a} S)$ and it is like that for San Paslihati-kum wa-PamtiSati-kum (Q4:102), he gives a little bit of the taste to the $t \bar{a}$ ? for both of them of the ğarr". The fact that Ibn Muğāhid makes a distinction here between giving the taste

$27 \quad$ Technically speaking the vowel $\bar{a}$ may be pronounced overlong, i.e. qāārrabbukum, as long vowels before long consonants are regularly lengthened. 
of the vowel $u$ and $i$ suggests first of all that we are not dealing with Pišmām in the technical sense (which cannot apply to $u$ ), but also that these vowels were distinct (i.e. it is rawm) and it is not merged into a single epenthetic vowel $\partial$ as Owens suggests.

\subsubsection{Tanwīn Blocks Assimilation}

Whenever a noun has tanwinn, al-Pidgäm al-kabir cannot operate. This is explicitly stipulated for Pabū Samr's assimilation rules by ibn Muğāhid (117). Whenever tanwin is present, case vowels are also present. It seems possible to argue that a caseless version of Pabū Yamr's reading had tanwin but no distinction between case vowels before it. In that case, ?abū Yamr's reading would be similar to modern dialects with 'dialectal tanwīn' (Stokes 2020). There is however nothing to indicate that this is the case, and the $i$-umlaut Pima a lah still cause by the genitive case in the indefinite rather argues against this.

\subsubsection{A Non-literalist Reading of $3 a b \bar{u}$ Samr's Traditions}

Owens admits the problems with his theory brought up by the $i$-umlaut and tanwin. But, he argues for a "non-literalist" reading of Pabū Yamr's tradition: "Against a literalist reading, I would argue that the status of many grammatical elements in the Qiraa?aat tradition still awaits comparative treatment, and that in some instances reconstructed forms may be necessary, which are not attested directly in any single variant" (Owens 2006, 132). While the complete transmission of ?abū Yamr indeed only first appears in the fourth century AH, ${ }^{28}$ several centuries after Pabū Yamr's lifetime (d. $154 \mathrm{AH}$ ), the transmissions of his reading among different authorities are independent enough that we can be reasonably confident that the features, along with those that require the presence of case vowels can be confidently attributed to him. Nevertheless, I believe that Owens does observe something important in his discussion of ?abu Samr's recitation, and that his "non-literalist reading" of the tradition is warranted. Througout Pabū Yamr's reading along with traces in Ibn Katīir's reading we see a fairly frequent cases of syncope (or ultrashort realization) of the ?i $i r \bar{a} b$ vowels $i$ and $u$ in phonetically very similar environments. While for neither reader this syncope is regular, the conditioning in which it occurs is consistent, and seems to reflect at least a memory of a variety of Arabic that had a case system quite distinct from that of Classical Arabic. Thus, Ibn Muḡāhid (155f.)

28 Ibn Muǧāhid's description is in fact extremely short and of little help to a person who would want to recite Pabū Yamr's reading with assimilation. His student Ibn Xālawayh has a more detailed description, which does not differ significantly from later descriptions (Ibn Xālawayh Badī؟, 307-317). 
mentions several cases where word-final $u$ and $i$ are either pronounced ultrashort $(\breve{u}$ or $\breve{l})$ or syncopated altogether whenever heavy pronomonial suffixes

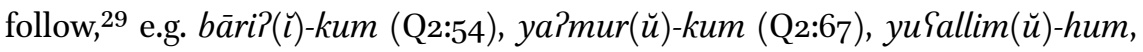

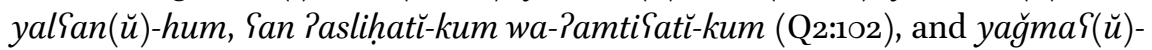
kum (Q64:9). ${ }^{30}$ Among his canonical transmissions there are many more cases of shortening like this, and even complete loss of Pi $i r a \bar{b} b$ is reported. This is broadly transmitted for the words $\operatorname{ba} r i ?(\breve{l})$-kum, ya?mur $(\breve{u})-k u m$, ya?mur $(\breve{u})$ -

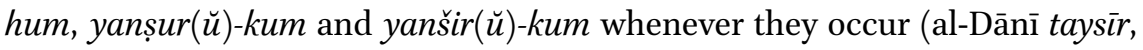
73), but Ibn al-Ǧazarī (Ibn al-Ğazarī, § 2655) brings marginal transmissions of many more cases, some even transmitting that every verb that ends in $\mathrm{ru}-\mathrm{h} / \mathrm{kum}$ loses or makes ultrashort the mood ending of the verb. Traces of a similar process can also be found in the canonical transmissions of Pabū Yamr's Meccan teacher Ibn Kațīr who read Par-nā (Q2:128; Q4:153; Q41:29) and ?ar-nī (Q2:26o; Q7:143), for the C-stem imperative of of $r a ? \bar{a}$, and Pabu Yamr follows him in this as well, though some transmit an ultrashort vowel Parı̆-nāa $/ n \bar{\imath}$ instead (Ibn al-Ğazarī, § 2728). It is worth pointing out that Ibn Muhayṣin, one of Pabū Samr's other Meccan teachers and one of the 4 pseudo-canonical readers after the 10, seems to have had a much more regular application of this syncope than either Pabū Yamr or Ibn Katīi (Sabṭ al-Xayyāt al-Mubhiğ, II, 370). ${ }^{31}$

While this system is not regular, it seems clear that the traces that are present here are related to a phenomenon that is reported as a dialectal tendency of Tamīm and Pasad, which happens, according to al-Farrā? (Luġät, 30) "because of the continuous succession of vowels" (tawātè al-harakāt) citing forms such as ya?mur-kum, yahzun-hum, ?a-nuzlim-kumū-hä, ?ahad-hum, ?ahad-humā, liPahad-himā. He explicitly points out that "the people of the Hijaz pronounce this clearly and do not weaken it, and this is the more preferable of the two options to me (wa-huwa Pahabbu l-wağhayni Pilayya)." Considering that this only affects the high vowels $u$ and $i$, among Najdi tribes, it seems that this should be considered to be part of the broader syncopating tendencies of $u$ and $i$ among these tribes (as discussed in $\S 2.2 .4$ and $\S 3.3 .2$ ). In this pattern, it seems worthwhile to also mention the existence of a different type of syncope before heavy suffixes in Pabu Yamr's reading, that is the syncope of the vowel

29 The opinion that Pabū Yamr pronounced these vowels ultrashort rather than syncopating them altogether seems to be an ancient one. Even Sībawayh (IV, 2O2) already explicitly mentions the reading of Pabū Yamr bāriř̌kum with an ultrashort vowel.

$30 \quad$ N.B. explicitly without neutralization of these short vowels.

31 Ibn al-Ǧazarī (IV, 2165) cites Ibn Muḥayșin as reading yufallim-hum, naḥ̌sur-hum and Pahad-humā (Ibn al-Ğazarī, IV, 2165). I have been unable to find reports of the reading Paḥad-humā for Ibn Muḥayṣin. 
before the case vowel of subul and rusul (and in a non-canonical transmission nuzul) before heavy suffixes, e.g. ruslunā, rusluhum, ruslukum, nuzluhum etc. (Ibn al-Ğazarī, § 2678; Ibn Muğāhid, 623).

While it seems that the transmission of Pabū Yamr's reading tradition is stable enough that we can be reasonably confident that he indeed had the rather irregular and incomplete system of syncopation that is reported for him, but in a non-literalist interpretation of the reported fact, we can certainly see how Pabū Yamr and his Meccan teachers Ibn Katīi and Ibn Muhayș̣in clearly retain the memory of a regular system of syncopation, similar to the one that alFarrā? describes. This would not lead us to conclude that their readings (or their ancestral predecessors) were entirely caseless, but they do point to a more reduced case system, where in some environments $u$ and $i$ dropped out completely, neutralizing the case contrast between the nominative and the genitive. It is worth noting here as well that when it comes to Pabu Yamr's ?idjām kabir a distinction in treatment between $u$ and $i$ as against $a$ can be observed as well. When assimilating dissimilar consonants, more phonotactic environments allow assimilation when $u$ or $i$ intervene than when $a$ intervenes. For example, a superheavy syllable due to the assimilation of $d \bar{a} l$ may only happen if the vowel in between is $u$ or $i$, e.g. min baSdi zulmih $\bar{\imath} \rightarrow$ min bafzzulmihī (Q5:39) and yurīdu zulman $\rightarrow$ yurizzzulman (Q3:108) but no assimilation in båda zulmihī (Ibn al-Ğazarī, §1169).

That the dropping of the case vowels $u$ and $i$ was considered ideologically problematic already very early on is quite clear. We have already mentioned alFarrā?'s opinion that forms without syncope are better, and a central part of disagreement within Pabū Yamr's transmissions are the many conflicting opinions as to whether he read the words under discussion above ultrashort or with no vowel at all. This controversy about $3 a b u \bar{~}$ Yamr's reading was clearly already set in motion the generation after his lifetime (he dies 154AH), as Sībawayh (d. ca. $18 \mathrm{OAH}$ ) already explicitly takes the stance that $\mathrm{Pabu}$ Yamr did not drop the vowel in bärî̌̆-kum, but instead pronounced it ultrashort (Sībawayh, IV, 2O2).

In conclusion, we can say that there are aspects of ?abū Yamr's reading that irregularly, but frequently point to this dialectal tendency to syncopate the final short vowels $u$ and $i$ in when they are suffixed by heavy pronominal clitics. This, along with reports of grammarians like al-Farrā?, certainly shows that in the second century AH the strict Classical Arabic (never syncopating) case system did not have the universal prestige that it holds today. Moreover, it seems to suggest that speakers of dialects of Tamim and Pasad indeed did not have a system that fully conformed to the standard Classical system. However, the evidence does not allow for a reconstruction a recitation of the Quran attributed to Pabu Samr, or his teachers that lacked the final short vowels and tanwin altogether. 
It also clearly points to a different case system than the one Van Putten \& Stokes (2018) have reconstructed for Quranic Arabic on the basis of the QCT.

\subsubsection{Hamzah's Pidjāam kabīr}

While ?abū Yamr's major assimilation is clearly part of a regular, but quite likely artificial, system of reading, making it difficult to see these as traces of a Quran without final short vowels, this major assimilation also occurs in Hamzah's reading. In his reading, however, it is not the result of a regularly recurring system, but just forms a set of lexical exceptions, which cannot be understood from the regular linguitic systems of Ḥamzah's reading (Ibn al-Ǧazarī, §11941195):

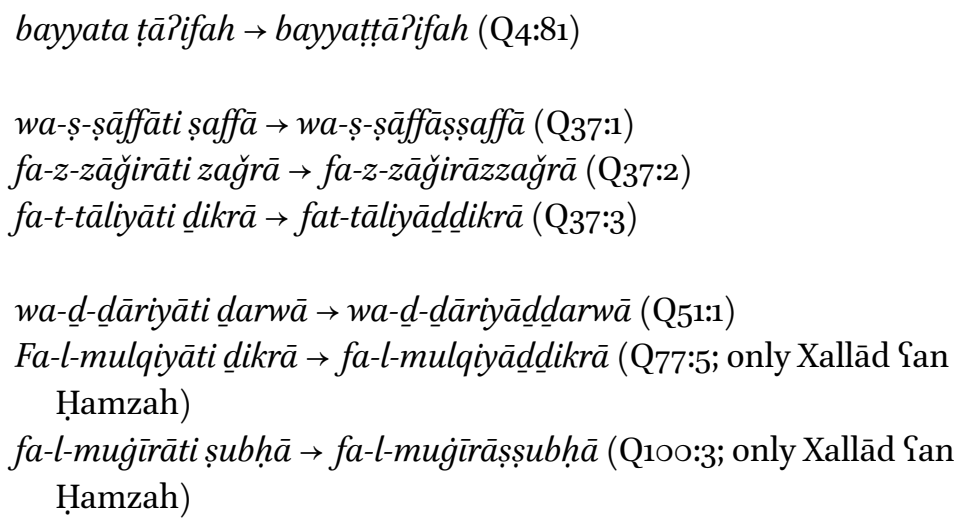

Seemingly equally eligible phrases are not included. For example, fa-s-sābiḥāti sabhāa, fa-s-sābiqāti sabqū (Q79:3-4) never assimilate.

Especially because it does not seem to be part of a larger system it becomes tempting to see these as genuine transmissions of forms without case vowels. But here too, as with ?abū Yamr's reading, this may be a memory not of a caseless recitation of the Quran, but rather one with a more pervasive assimilation across word-boundaries.

\section{7·3 A Phonetic Rule That Requires Absence of Full Pifrāb}

Throughout the Quranic reading traditions, once occasionally finds forms that, in principle follow the classical ?i iräb system, but whose distribution cannot be understood within such a system. An example of this is the inflection of mayyit 'dead' in the reading of Ḥaf̣̦ Gan Yāṣim, Ḥamzah, al-Kisā?ī, and Xalaf. These readers have the short form of the stem mayt- whenever is occurs as an indef- 
inite masculine accusative or in any form of the feminine. The distribution as formulated for the four Kufans exactly matches the distribution as described by al-Farrā? $(L u \dot{g} \bar{a} t, 47)$ and has been tabulated below:

\begin{tabular}{llll}
\hline & Indefinite & Definite & Feminine \\
\hline nom. & mayyitun & - & al-maytatu \\
gen. & mayyitin & al-mayyiti & - \\
acc. & maytan & al-mayyita & al-maytata, maytatan \\
\hline
\end{tabular}

Pabū ĞaYfar always has the uncontracted form, whereas YaYqūb and Nāfí mostly follow the pattern of the four Kufans mentioned above but Nafî has an uncontracted form at Q36:33 al-mayyitatu, Q6:122, Q49:12 mayyitan and Q7:57, Q35:9 mayyitin. Ya१qūb has Q6:122 mayyitan uncontracted and Ruways Yan YaYqūb also reports Q49:12 mayyitan. The remaining readers always have the shortened form (Ibn al-Ǧazarī § 2745).

It is difficult to make sense of the Kufan distribution if we assume that full Pi $i$ rāb was present. Why, for example, would the following short $a$ in al-maytata cause shortening of the stem, whereas in al-mayyita it does not? However, if we take the forms that Van Putten \& Stokes (2018) reconstruct as the case system of Quranic Arabic as the basis, i.e. a system identical to the Classical Arabic "pausal" pronunciation, the distribution becomes readily transparent: the vowel $i$ simply syncopates whenever it stands in an open syllable, an exceedingly common phonological development in the modern Arabic dialects as well. Only the indefinite accusative $-\bar{a}$ and the feminine ending - $a h$ would have this environment.

\begin{tabular}{llll}
\hline & Indefinite & Definite & Feminine \\
\hline nom. & mayyit & - & al-maytah \\
gen. & mayyit & al-mayyit & - \\
acc. & maytā & al-mayyit & al-maytah, maytah \\
\hline
\end{tabular}

The only way I see how this distribution can be explained as being present in the Quranic recitations with its Classical Arabic case endings is by assuming that these forms stemmed from a variety of Arabic that had a case system 
just like the one Van Putten \& Stokes reconstruct for Quranic Arabic. The fact that grammarians report this—-to them morphological—conditioning with the Classical Arabic case endings, is a clear example of Grammarians "classicizing" their dialectal data. The Pi $i r a \bar{b}$ was felt as such a central part of proper Arabic, that all linguistic data gets filtered through that lens, regardless of whether this is appropriate or not. ${ }^{32}$

Traces of similar cases of syncope, seemingly triggered by an originally reduced case system may also be found in the distribution of some of the $\mathrm{CuCuC}$ nouns. For example, for nudur 'warnings' is universally unsyncopated among all Quranic readers when it is in the definite form, or in the nonaccusative indefinite. But Ḥaf̣̦ Yan Yāṣim, Rabū Yamr, Ḥamzah, al-Kisāīī and Xalaf all syncopate this word in the indefinite accusative nudran, while the rest reads nuduran. It is probably no coincidence that the readers that read in this manner are the same ones that have the mayyit maytā alternation (Ibn al-Ğazarī, §3694). ${ }^{33} \mathrm{~A}$ similar distribution is attested for nukur 'denial' which is read without syncopation in the non-accusative form by all readers but Ibn Katīr. The indefinite accusative however, is read as the syncopated nukran by a once again familiar list of readers: Ḥaf̣̣ Yan Yāṣim, Ḥamzah, al-Kisā?ī, Xalaf and ?abū Yamr. In this case also Hišām Yan Ibn Yāmir has the syncopated form (Ibn al-Ǧazarī, § 2685$) \cdot{ }^{34}$

\subsection{Conclusion}

We have argued that two main features that distinguish the Quranic reading traditions from the language as it is reflected in the QCT are the introduction of

32 This is a trend we will continue to see throughout the history of linguistic writings within the Arabic tradition. For example the famous Himyaritic sentence رأيك بنخلم كولدك ابنا من طيب "I saw in the dream that I gave birth to a son of Gold", where 'son' is conjugated as ibnan, with the Classical Arabic indefinite accusative, must probably be seen as classicization of a form of the language which was clearly rather far removed from Hijazi and Classical Arabic (Rabin 1951, 48). Rabin likewise quotes a few lines of apparent Himyaritic poetry, where he quite rightly comments that "there is obviously some admixture of Classical Arabic": yā bna Zubayrin țāla mā Sașayka; wa-țāla ma Sannaykanā Pilayka; latahzananna bi-lladī Patayka; la-nadriban bi sayfina qafayka "Son of Zubair, long hast thou been disloyal, long hast thou troubled us to come to thee. Thou wilt be grieved for what thou hast committed (or: what is coming to thee). Yea, with our sword we shall cut off thy neck."

33 With the exception that Pabū Yamr is included in this distribution.

34 Ibn Katīi also has the syncopated form, but he also syncopates the genitive form nukrin (Ibn al-Ǧazarī, §2688). 
the hamzah and the use of the full Classical Arabic system of final short vowels and nunation. If my thesis is correct in this regard, this must mean that these features were consciously introduced into the Quran, and that Quranic Arabic has been "linguistically reworked" by the early Arab philologists. In the case of such reworking, one would probably expect to see traces of this process. It should be clear from the previous and current chapter that these occur in copious amounts.

There are many examples in the reading traditions where the hamzah was artificially inserted in places that never etymologically had them, and likewise there are many more examples of words that inexplicably lack the hamzah, where for all intents and purposes we would predict that the regular rules of the treatment of hamzah in these readings would have required them. From this behaviour we should conclude that the early Arabic philologists did not always have access to accurate information on the place where the hamzah should appear, and would make their own (sometimes incorrect) rationalizing judgments. This is explicitly admitted by the tradition. We have fairly credible early reports of some of the canonical readers specifically commenting on their rationalization process in applying the hamzah.

Demonstration of a change in the case system is more complex. The Pi $i$ ra $b$ and tanwin system being the quintessential feature of Classical Arabic, and therefore the one feature that binds together all of the reading traditions, it is of course impossible to recover from these traditions a reading that lacked this feature altogether. Nevertheless, close examination of the readings does reveal that here too, we see that the application of Pifrāb and tanwin was not a matter of accurate transmission from a prototypical source, but rather a rational endeavour. We have a direct citation from the student of al-Kisā?ī of him citing explicitly aesthetic arguments why he chose to conjugate tamūd in a certain way. Also, a form like ?ayyāna, which quite rightly, is analysed as coming from Payya ?ānin, can only be understood as a hyperclassicism of an input that lacked case vowels altogether. The fact that some words among the readers such as mayyit/maytah/maytā seem to undergo syncope conditioned by a case system different from the Classical Arabic system - but rather the one that can be reconstructed for Quranic Arabic, is a clear indication that the case system has been imposed onto the Quranic language.

Furthermore, there are a good number of cases where final short vowels, and in one case tanwin, are inexplicably missing. This even seems to be a regular phenomenon for apocopate/imperative III- $y / w$ verbs followed by a pronominal suffix for some readers. Considering the ideological commitment to ?ißrāb and tanwin, showcased by the many injunctions not to recite the Quran without it (see Kahle 1947, 49-84; 1948; 1949), it is difficult to see how such unclassical 
forms would have entered the language, if they do not point to some genuine attempt to retain the proper recitation of such words.

While Vollers was, as Owens (2006, 77, n. 42) put it, "essentially shouted down [...] by his German colleagues" for his views on the language of the Quran, it is especially his arguments for this reworking which I believe have not been given the adequate evaluation that they deserved. Vollers' arguments for a wholesale transition from an Ur-Quran without case to the fully Classical case inflection were indeed rather weak, ${ }^{35}$ but one thing he does conclusively show is that the readers of the Quran clearly reworked the readings according to grammatical and philological principles. As Vollers did not rely on very direct sources on the reading traditions, ${ }^{36}$ he missed many cases of such artificiality in the readings that I have shown in chapter 3, 6 and the current chapter, but nevertheless on many occasions noticed clear cases of pseudocorrection among both canonical and non-canonical readers (such as the canonical reading of sa?qay-hä for sāqay-hā).

Nöldeke $(1910,1 \mathrm{f}$.) criticized Vollers for not realizing that many of the readings cited as evidence for philological reworking of the Quran are canonical. ${ }^{37}$ But these readings being accepted as canonical does not alleviate the problem that Vollers highlights. Nöldeke admits that the recitation of the Quran was linguistically reworked, but believes that under the layers of artifice a true language always shines through (Nöldeke 1910, 2). But how can we be so certain that it is the "true language" that shines through? What philological evidence based on primary source material of the Quran has been adduced? Nöldeke, nor any of Vollers' other critics ever adequately address this crucial point. Why would this one central feature - one so laden with ideological commitment as the ?i Y $r \bar{a} b$ system - be the one system that the readings accurately reflect while so many other features carry "artificial decorations"?

35 Although these arguments have only been seldomly adequately addressed by his critics. See Van Putten \& Stokes $(2018,145$ f.) for a discussion.

$3^{6}$ He primarily relied on reports found in the ?anwär al-Tanzill wa-?asrār al-Ta?wïl by the very late scholar Nāșir al-Dīn al-Bayḍāwī (d. 685AH) for his information on the Qirā?āt.

37 This was a misrepresentation of Vollers' understanding of the situation, e.g. Vollers (1906, 25) explicitly speaks of "al Kisẩi († um 180), einer der kanonischen Qorânleser", clearly showing awareness of this distinction. While it is an unfair criticism of Vollers, it would in fact have been a perfectly reasonable criticism of several scholars who would later give his work short shrift, such as Wehr (1952) and Zwettler (1978). Both authors seem to be almost entirely unaware of the existence of any linguistic differences of the Quranic reading traditions and what effect this may have for our understanding of what the farabiyyah is. 
As it is clear that all the canonical Quranic readings (and as far as we can see, also the non-canonical ones) have been linguistically reworked, we must be careful to generalize from these sources to make any pronouncements about the original language of the Quranic composition. Of course, that is not to say that the reading traditions are devoid of interest to the researcher who wishes to reconstruct the language of the QCT, and indeed its original composition. The linguistic variation found in the reading tradition is a massive font of linguistic data that allows us to gain insight into the kinds of linguistic variation that existed in the literary language of the early Islamic period. The transmissions of this data frequently predate the activity of our earliest grammarian authors, and record wider linguistic variation. These allow the researcher to quickly generate a number of different hypothetical pronunciations, which may then be checked against the QCT. An example where the reading traditions clearly retain the original linguistic situation as reflected in the QCT can be found with the preservation of a word-final $\bar{a} / \bar{e}$ contrast as preserved in the readings of al-Kisāīì, Ḥamzah, Xalaf and Warš Yan Nāfị, which rhyme and orthography of the QCT clearly show are an accurate reflection of the system as found in Quranic Arabic.

If it is the case that all of the Quranic readings, canonical or otherwise, have been linguistically reworked, how can we be certain that any part of these readings is in any way a reflection of the actual language as intended by the QCT, or indeed of its original composition? This question simply cannot be answered, as it traditionally has been, through the sole examination of the Arabic literary tradition. I hope that this work has shown that the tradition is too late, too artificial, too contradictory and too ideologically invested in the ideal of the Sarabiyyah to function as the sole reliable source on the language of the Quran. For this reason, we must turn to the actual primary source material that is by far the closest to the time of composition of the text: the Quranic Consonantal Text itself. 